\title{
THE AMOROUS QUEEN AND THE COUNTRY BUMPKIN: CLYTAEMESTRA AND EGISTUS IN DRACONTIUS' ORESTIS TRAGOEDIA
}

\author{
Betine van Zyl Smit (University of Nottingham)
}

This paper investigates the depiction of Clytaemestra and Egistus in the narrative poem of the North African poet, Dracontius. A close reading of the Latin epyllion explores the similarities and differences between this Clytaemestra and Egistus and their representation in the Greek and Roman tradition.

The Orestis tragoedia, in spite of its title, is a miniature epic poem or epyllion, ${ }^{1}$ composed, it is now generally agreed (Bouquet \& Wolff 2002:8) by the North African poet, Blossius Aemilius Dracontius. The little that we know of his life is based on information in his work. ${ }^{2}$ His date of birth is assumed to be around AD 450 and he probably lived in or near Carthage until the early sixth century. He was the last author in the Latin West to write mythological epic poetry (Schetter 1994:342). These poems are known as the Romulea. Although pagan culture was no longer dominant in political life and Dracontius wrote some works that were overtly Christian, pagan literature still played a decisive role in education. The educated elite of the time were well versed in this culture and it is by no means unusual for a poet to render new versions of pagan mythology without turning them into allegories with a Christian message. ${ }^{3}$ The very fact that scholars disagree $^{4}$ about whether the Romulea poems also contain a Christian message indicates that this was not the poet's primary purpose.

This paper argues that Dracontius' aim was rather to be innovative in transferring a myth more traditionally treated in drama to another genre, as highlighted in his invocation to the muse of tragedy, Melpomene, to descend from the tragic buskins and to exchange iambics for dactylics (13-14).

1 For the genre of epyllion, see Crump 1978, Bright 1987:vii-ix, 3-8 and Bouquet \& Wolff 2002:37-43. References to the Orestis tragoedia are to the text in this volume $L a$ Tragédie d'Oreste, 87-130, 161-242.

2 For a succinct sketch of the background and context in which Dracontius lived, see George 2004:133-143.

3 Schetter 1994:367-369 convincingly refutes the interpretation of the Orestis tragoedia as a theological parable.

4 Kaufmann 2005 presents a nuanced argument in favour of a Christian reading of Romuleum 10, Medea, while Bouquet \& Wolff 2002:43-45 totally reject such explanation of any of the poems. Edwards 2004:152 goes even further in describing the Romulea as "so empty of Christian teaching that we are tempted to doubt the allegiance of the author". 
Te rogo, Melpomene, tragicis descende cothurnis et pede dactylico resonante quiescat iambus.

I ask you, Melpomene, descend from the buskins of tragedy

And let iambic metre rest while the dactylic foot resounds. ${ }^{5}$

It is noteworthy that the change of genre is announced as a lowering (descende). It is tempting to see here an indication of the domestication of the story which is usually presented in the tragic genre.

In addition to the change of genre, Dracontius alters the focus of the narrative to the love of Clytaemestra and Egistus and presents their relationship as adultery. The poet pays scant attention to the themes of fate and destiny prominent in dramatic treatments of the myth. This paper will investigate how Dracontius, by changes in elements in the traditional mythical tale, and by his characterisation of Clytaemestra, Egistus and Agamemnon, turned the story into an account of the evils of adultery.

The little epic of 974 hexameter lines, packed with narrative detail, retells most of the myth of Orestes. That means that Dracontius has incorporated not only the material from Aeschylus' Oresteia, but also incidents that figure in other tragedies such as Sophocles' Electra, Euripides' Orestes and Iphigenia in Tauris. The question of whether Dracontius knew Greek and read these dramas in the original, remains open, ${ }^{6}$ but scholars have traced echoes of many Latin poets in his work. Different versions of the murder of Agamemnon had been scripted by various Romans. Some of these works like Pacuvius' Doulorestes, Livius Andronicus' Aegisthus and Lucius Accius' famous Clytemnestra ${ }^{7}$ are preserved only in fragments, but we do have Seneca's Agamemnon which presents a very different Clytaemestra to that of Aeschylus' tragedy of the same name. Roswitha Simons (2005:7) notes that it is characteristic for Dracontius to ring the changes on well known myths by combining various traditional versions that usually appear separately and mostly in genres other than epic. This is supported by Fontaine (1981:21) who remarks that the literature of late antiquity is characterised by a mixture of models, genres and tones.

In addition to retelling all the incidents of the Orestes myth: the murder of Agamemnon, Orestes' revenge through matricide, his madness, his healing and the trial on the Areopagus, the poem includes Orestes' visit to Tauris and encounter with Iphigenia as well as his killing of Pyrrhus. These two episodes are inserted between the matricide and the trial. Dracontius has added some new elements of

All translations are mine.

See Schetter 1994:346 for a brief discussion of the question.

7 Hall 2005:61 has details of the texts and productions in antiquity. 
his own, such as that Agamemnon visits Tauris and meets Iphigenia on his way home from Troy. He has also created the character of Dorylas, an old family retainer, who plays a role in helping Orestes avenge his father's murder. Dracontius has altered some of the details of the Greek dramas: as in Seneca's Agamemnon Clytaemestra immobilises Agamemnon in a tunic she has designed and Egistus kills Agamemnon with an axe. ${ }^{8}$ Dracontius follows Sophocles' Electra and Seneca's version (Aga. 929-934) of Electra saving Orestes from their mother's murderous intention. These changes of plot in larger or smaller respects create a fast-moving and rather melodramatic story. The most profound alteration that Dracontius has made, however, is to present the mythical events not as the working out of a family curse and of cycles of revenge, but as the gruesome consequences of adultery. This theme, the evils of adultery, is also prominent in another of his poems, De Raptu Helenae. ${ }^{9}$ The adulterous aspects of the relationship between Clytaemestra and Egistus are thus brought to the fore, and this has resulted in a more sensuous and sexualised couple.

Dracontius' secular poetry shows a predilection for accounts of romantic love, as is evident in the portrayal of Medea's love for Jason in his Medea and the love of Helen for Paris in De Raptu Helenae. The overwhelming passion of Clytaemestra for Egistus provides a sustained theme in the Orestis tragoedia. The dominance of their passionate love is emphasised by downplaying or omitting some of the traditional reasons for her murder of her inconveniently returning husband, Agamemnon. ${ }^{10}$

In earlier works the motives for the murder of Agamemnon are an amalgam of the joint and several reasons of each of the adulterous couple of Clytaemestra and Egistus: on his part vengeance for the monstrous way in which Agamemnon's father, Atreus, not only stole the inheritance of Thyestes, Egistus' father, but turned him into a cannibal who consumed his own sons, and also a desire to reclaim the throne. Clytaemestra is traditionally spurred by the desire to avenge the treacherous sacrifice of Iphigenia as well as Agamemnon's infidelities which culminate in his bringing Cassandra back to Argos. Jointly the pair are driven by lust and political ambition.

8 Aeschylus has Clytemnestra stabbing him to death. Edith Hall 2005:60 notes that when Aegisthus is shown as Agamemnon's murderer, he "invariably uses a sword", while Clytemnestra is usually "associated with the "manslaying axe"" that she calls for in Libation Bearers 889. It is not unusual for Dracontius to differ from traditional versions of the myths in minor details.

9 References to De Raptu Helenae are to the text in Wolff 2002:13-40, 114-173.

10 Mader 1988:52-53 has a useful summary of how the different major Greek authors treat Clytaemestra's motivation for murdering her husband. 
In the Orestis tragoedia, however, the passionate physical love affair of Clytaemestra and Egistus blots out the background of the family curse. Egistus is not the avenger of the wrongs inflicted on Thyestes by Agamemnon's father. ${ }^{11}$ That they are cousins is never mentioned. The accent is rather on forestalling Agamemnon discovering, ending, and punishing their adultery. In this way the plot is that of a family drama of a more superficial kind. Dracontius' Clytaemestra does not cite the sacrifice of Iphigenia as a motive, nor is Agamemnon's infidelity and his introduction of a concubine a reason. In fact this Agamemnon is a good husband and Cassandra is no more than his captive. By presenting an Agamemnon who is not an adulterer Dracontius stresses the emphasis on the adulterous behaviour of Egistus and Clytaemestra. This change in motivation contributes to a different conception of Clytaemestra. Not only is she unconcerned about Iphigenia, ${ }^{12}$ she is rather hostile to Electra and Orestes as well. Her only concern, one could say obsession, is with Egistus. She is totally besotted with him. ${ }^{13}$ This seems to be a characteristic of Dracontius' version of the myths, the female characters are strong and act to promote union with the men they love; the male

11 There are very few references to Egistus' ancestry: in 203 heredem seruo Thyestis (I am saving the heir of Thyestes), but the text is uncertain here, see Bouquet \& Wolff 2002:176, footnote 158. Clytaemestra is trying to convince Egistus of the necessity to kill Agamemnon. In 308 when Egistus, after the murder, enters the palace tanquam legitimus heres Agamemnonis, (as if the legitimate heir of Agamemnon), Dracontius parenthetically adds: et magis heredem conuenerat esse Thyestis (and it was more suitable that he was the heir of Thyestes). Bouquet cites Rossberg's comment that this can be understood only as Dracontius here conceiving Thyestes as a simple peasant and not a king. In 486 in the words Ad regna Thyestis, Dorylas is appealing to Agamemnon's spirit and noting that the Furies will come "to the realms of Thyestes", a route well known to them. As Bouquet remarks (191, note 316), the ancestry of Egistus plays a minimal role in the O.t. in contrast to its importance in the tragedies of Aeschylus and Seneca.

12 Clytaemestra's only reference to Iphigenia is that she is not a threat to their plan to murder Agamemnon as she is cinders in Diana's temple (194: unaque natarum cinis est per templa Dianae).

13 The emphasis on Clytaemestra's sexual motivation is much more concentrated than in previous Latin poets. Propertius lists her love for Aegisthus and its consequences as a notorious instance of disaster caused by female lust and adultery (Prop. 3.19. 19-20). Ovid does present what Hall 2002:63 terms a "sexy heroine" in $A A 2.387-408$, but that is only in retaliation for Agamemnon's infidelities. Seneca's Clytaemestra, (Hall's "neurotic adulteress", 63), in addition to her passion for Aegisthus, is sexually jealous of Cassandra, still in love with Agamemnon and also avenging the death of Iphigenia. But she is morally conflicted and has some feelings of pudor (Aga. 138). Mader 1988:64-65 and Croisille 1964:464-472 indicate the complexity of Seneca's Clytaemestra. 
characters are weak and easily manipulated by their mistresses. ${ }^{14}$ The men are insipid and less manly or heroic than their classical counterparts. Dracontius has created an Egistus who is not only weak-willed, but is the opposite and inferior in every way to Agamemnon. The adjectives and qualifications that mark him, especially pastor, point to a humble background, limited experience and lack of sophistication. He is depicted as indecisive, cowardly and vulgar, a vile parvenu. ${ }^{15}$

The portrayal of Clytaemestra as a woman in love is achieved partly, as already mentioned, by altering her motives for murdering Agamemnon. The main reason for Agamemnon's elimination is that his return is a stumbling block to her adulterous relationship with Egistus (120). While that is usually an underlying reason for murdering her husband, its prominence is part of the emphasis on the nature of Clytaemestra's love. She thinks of Egistus all the time (123), the worst of death would be that it would end their love (168-169) The sensuous nature of their relationship is emphasised $(128,226-231)$ throughout, for instance by the use of the adjective lascivus "lustful" to designate each of the couple. The location of Agamemnon's murder, in the bedchamber, injects a strong element of the macabre into their adultery. Clytaemestra maintains the physicality of her love for Egistus until death. She wishes to die on Egistus' body, for their blood to mingle (755-766), but this is refused by Orestes who is not only avenging the murder of his father, but also punishing his mother for her adultery.

The theme of marriage and adultery runs through the entire poem. It is signalled early when Agamemnon is described in line 23 as thalami uindex, "avenger of the conjugal bed" who, ironically, is murdered under the eyes of his wife and in sight of his own marriage bed:

criminis ultorem dum criminis amputat auctor

et thalami uindex thalamo ${ }^{16}$ spectante necatur, ante toros iacet ille tori genialis amator.

14 Cf. Medea's initiatives in Dracontius' Medea and Helen's in De Raptu Helenae. Both Clytaemestra and Helen refer to their lovers as iuvenis, O.t. 163, 334; De RH 551 in situations where they take the initiative and instruct their "young men" on what action should be taken.

15 "Bref c'est un vil parvenu dont le poète rappelle l'humble extraction à maintes reprises", Bouquet \& Wolff 2002:33.

16 Bouquet 2002:91 notes that thalamo by metonymy here is equivalent to coniuge, but, in my view, it implies both the marriage and the wife, the first in the usual meaning of the word, and the second in the personification in the ablative absolute with spectante. Dracontius thus also plays upon the contrast thalami ... thalamo as he does with toros ... tori in the next line. I have rendered the two meanings in a very literal translation of the lines: While the author of the crime cuts down the punisher of crime, and the avenger of the marriage bed is murdered within sight of the marriage bed / with his wife looking on, and the famed friend of the nuptial couch lies before the couch. 
The emphasis in describing Agamemnon shifts from the traditional view of him as conqueror of Troy, to more prominence to him as avenger of the adultery of Helen and Paris (criminis ultorem, cf. ultor adulterii 508), which sullied the marriage of his brother, Menelaus. The explicit parallels between the situations of Agamemnon and Menelaus are encapsulated in an aside in Dorylas' appeal to Agamemnon's spirit:

nonne laborastis, Helenam ne pastor haberet?

469

Ecce, tuam nunc pastor habet!

What a struggle you had so that the herdsman should not have Helen.

And look, now a herdsman has your wife!

Clytaemestra and Egistus are throughout not only presented as treacherous criminals, but as conscious of their crime. ${ }^{17}$ Clytaemestra especially is fearful of Agamemnon's return and the punishment that the avenger of adultery will inflict on the adulterous couple within his own house (metuens, impura adventus mariti 115, the scandalous woman was fearing the return of her husband); adultera, regia coniux ... anxia ... pauore $117-119$, the royal wife, the adultress, ... stricken by anxiety; supplicium expectans scelerum ueniente marito ... timore 120-121, fearfully expecting punishment for her crimes when her husband arrived).

Dracontius introduces Cassandra's prophecies much earlier than Aeschylus where she utters them directly before the murder, or Seneca where she describes the deed as it is executed. In fact Cassandra arrives ahead of Agamemnon who has made a detour to Tauris. Immediately she catches sight of Clytaemestra, she challenges her to carry out her murderous designs which will make her the one who avenges the Trojans and brings consolation to Trojan widows. Cassandra's clairvoyance accurately defines the squalid background of Egistus who is more accustomed to huts and animal hides, than royal halls and downy pillows (139-141). She also refers to him as ferox adulter (149). She is equally frank about their motive for the murder: to ensure the continuation of their love (143). Cassandra's words terrify the guilty pair $(153,157)$, but paradoxically, although she has been warned that if they kill Agamemnon, Orestes and Pylades will take revenge by killing them, Clytaemestra now sets about preparing the murder although it has not before been indicated as her plan. Bouquet (2002:172, footnote 116) criticises the earlier introduction of Cassandra's prophecies as lowering the dramatic intensity, but I would argue that the effect is to highlight the

17 Clytaemestra rejoices that her crimes can remain unpunished when Agamemnon does not arrive in the first ship back from Troy: impunita putans sua crimina posse manerel gaudet 125-126 (She rejoices, thinking that her crimes can stay unpunished). 
determination of Clytaemestra to try to preserve her adulterous relationship against all odds.

In addition to her sensuality, Clytaemestra is shown as a capable and clearheaded planner and strategist. She persuades the timid Egistus to kill Agamemnon (163-203) by playing on his emotions. First she represents Agamemnon as a bloodthirsty avenger who will punish them, but later as a sitting duck who has no inkling of the danger awaiting him in his home. She herself assumes the role of weak and frightened woman to Egistus' strong man, but at the same time, she is the queen and he the pastor. Clytaemestra plans the murder (209-217) and participates in its execution (250-264). She deploys clever rhetoric even under pressure, and has the courage to summon the people of Argos, incensed by the murder of their king and to face and address their assembly (381-411). In her speech she blackens the character of Agamemnon, offers sympathy for the plight of ordinary people during the sacrifices of war and promises a period of tranquil happiness ahead with Egistus as a citizen king, civis (411) (a somewhat anachronistic concept!) ${ }^{18}$ and as her acknowledged husband. Later when Orestes returns, Clytaemestra does not give in to panic like Egistus, but tries to persuade Orestes not to kill her.

The portrayal of Egistus as an upstart, coward and bully also reflects badly on Clytaemestra. Her infatuation with this worthless hick and her hatred of her admirable husband indicate her skewed morality and underline the physical nature of her relationship with Egistus. Schetter sees Dracontius' changes to the traditional character of Egistus as one of the most prominent aspects of his innovation. ${ }^{19}$

Especially noticeable is Dracontius' use of pastor to identify Egistus. This may be linked to the etymology of his name Aigisthes = Aigi-sthenes, meaning "nourished by a goat or aix". This derivation is illustrated by Hyginus' account (Fabulae 87, 88 and 252) where the story is told of how his mother, Pelopia, victim of Thyestes' incest, exposed the infant she bore, but that he was then found by herdsmen, pastores, who had him suckled by a she-goat (caprea, Gr. aix). Hence he was named Aegisthus. Dracontius drew on this background and all the lack of sophistication associated with herdsmen, when he used the epithet pastor to denigrate his Egistus. It is consistently used pejoratively and in no sense of the word links to the bonus pastor or "good shepherd" of the

18 Dracontius' mythological poems often contain anachronisms from the Roman world. One of the most striking is Electra taking Orestes off to Athens to study at the Academy (286-288).

19 Schetter 1994:352 remarks that as an ordinary herdsman he is socially far beneath Clytaemestra and that is often reflected in the way she addresses him: iubeoque rogoque I pastorem regina monens 183-184, As a queen a herdsman, I command, request and warn [you]. 
New Testament. The Egistus of this poem is a crude peasant distinguished by all the negative qualities of a rustic, but none of the positives. Dracontius turned the son of Thyestes who was exposed at birth and brought up by herdsmen into a real, crude country bumpkin.

The epithe ${ }^{20}$ of pastor designating Egistus also points up the parallel between him and Paris, the Trojan shepherd who deprived Agamemnon's brother of his bride, Helen, Clytaemestra's sister. I counted at least seventeen uses of pastor to describe Paris in De Raptu Helenae. This is not surprising as it is part of Paris' traditional designation. Simons (2005:304-305) points out that Dracontius' Paris, although he is the son of Priam and, after exposure in infancy, is accepted back as a royal and enjoys all the outward trappings of the status, in essence retains his character as an outsider, a herdsman. Egistus, too, to whom the epithet is not usually applied, is singled out in this way and also by the synonym bubulcus (424) and the adjective rusticus (rustica colla 229), rustica membra (662). The lowly status of Paris and Egistus enhances the parallels between the two sets of adulterers which are invoked several times. These two lovestruck and perfidious couples: Egistus - Clytaemestra and Paris - Helen, are the cause of death and destruction: the Trojan war and the murder of an exemplary monarch and man. Egistus' base nature is again underlined when after the murder he first tries to track down Orestes to kill him and then attempts to find the Trojan loot that Agamemnon brought back. When he is baffled in both endeavours, he loses his temper (313-315) but is cunningly consoled by Clytaemestra (316-336) and by grasping the power of ruling the kingdom (337). The repressive regime of Clytaemestra and Egistus which Dracontius sketches (413-418) and condemns (419-422) is additional proof of their moral turpitude.

The moral bankruptcy of Clytaemestra and Egistus is further pointed up by the contrast with Dracontius' depiction of Agamemnon as a good ruler, good husband and good father. He is the legitimate king (25-30), repeatedly identified as rex, ductor, dux and princeps, while Egistus is an usurper. Dorylas refers to Agamemnon as optime rex (462). The ordinary people mourn their king and for years weep on his tomb (543-549), but detest the new regime. Clytaemestra and Egistus are adulterers while Agamemnon has not taken advantage of the opportunities to take Trojan concubines. Agamemnon not only shows his love for Iphigenia when he encounters her in Tauris, (he bursts into tears of joy (62-64) and the scene is one of mutual love and tenderness) but the responsibility for her sacrifice is that of Ulysses (76). Like a good father who has been away from home, he brings gifts back to his children (35-40) and to his wife. Conversely, Clytaemestra and Egistus seek to destroy Orestes and Electra. In keeping with the

20 Pastor to designate Egistus occurs sixteen times in the poem. 
literary tradition, Egistus is shown to be a coward who did not take part in the war, but Agamemnon is the leader and a hero marked by epithets like triumphans and bellipotens (26-27). The contrast between the treacherous couple and the worthy and blameless king returning home darkens the hue of their villainy.

The difference between Agamemnon and Egistus is emphasised by the poet in the immediate aftermath of the murder. Agamemnon is described as Asiae domitor (subduer of Asia) who has been felled by the axe of a herdsman, pastoralis securis (269-270). Again the gulf between the overthrower of Asia (euersorem Asiae 275) and his lowly murderer is stressed: Egistus is cultor agelli ... desertor iners, ouium pecorumque magister (275-276) — (farmer of a patch of land, ignoble deserter, master of sheep and cattle).

The condemnation of Clytaemestra and Egistus, their adulterous relationship and brutal murder, is given added emphasis when the poet appeals to his readers:

Sceptra triumphorum data sub pastore tyranno

pro pretio scelerum, mercedem sanguinis ostrum,

matronale nefas, uxorem dedecus aulae, quis, rogo, non gemeret?

Who, I ask, would not deplore the sceptres of the triumphant granted to a herdsman turned tyrant as reward for crimes, the purple as recompense for blood and the transgression of a wife, a spouse to disgrace a palace?

Bright (1987:153) rightly observes that such verses, where Dracontius adds his comments to the events he describes, represent the function of the chorus in the dramas which furnished much of the poet's material. It is undeniable that these remarks combine with the negative representation of Clytaemestra and Egistus to condemn their characters and actions.

The conflict between Clytaemestra and Orestes is a unifying thread that runs through the last part of the poem. Orestes is drawn as a son caught up between divergent duties to his parents: ${ }^{21}$ vengeance for his father's murder, and acknowledgement of his mother's nurture. Orestes' recognition (562-573) that Clytaemestra must have looked after him in his early years, is the most favourable view of the selfishly amorous queen in the poem. However Pylades persuades him that his mother deserves to die for her crimes. Dracontius eliminates the role of the gods who drive Orestes to vengeance and then haunt him for spilling his mother's

${ }^{21}$ Orestes is no longer, as in the Greek tragedies, the instrument of the gods. 
blood. He describes Orestes' action as springing from his own psychological development. In this respect Dracontius' treatment of the myth is closer to Seneca.

Orestes is first spurred to take action when Agamemnon appears simultaneously ${ }^{22}$ in dreams to him and to his close friend, Pylades. The two young men return to Argos from Athens where they have been studying. Dorylas welcomes them, and while Pylades kills the craven Egistus, Orestes sacrifices his mother to the spirit of his father (768-774). She is to be separated from her lover in death and dies on her husband's grave. Her death is retribution for Agamemnon's slaughter, but also, explicitly, punishment for her adultery. The poet allows Clytaemestra a dignified end (786-794). She takes care to cover herself down to her feet so that she might not be nude in death. This attempt to control her fate even beyond death is in keeping with the character Dracontius has created. However the poet's comment: vix semel, infelix, extrema in morte pudica (chaste only once, unfortunate woman, on the verge of death, 790) rather undercuts that gesture by reminding readers of her essentially unchaste character.

Dracontius incorporates another execution by Orestes into his narrative. Immediately after the traditional climax of the punishment of Clytaemestra and Egistus, news is brought that Pyrrhus has abducted Hermione, Orestes' promised bride. Pylades and Orestes pursue him and he too is killed by Orestes. After this deed Orestes is tormented by visions of his mother in the guise of a Fury armed with torches and serpents. Again Dracontius has altered the traditional religious motif to a psychological one. The cure for Orestes' madness is brought about by a visit to Iphigenia in Tauris. The poet covers these events rapidly and then transfers the action to the Areopagus in Athens where Orestes is prosecuted for two murders by Molossus, ${ }^{23}$ son of Pyrrhus. Molossus argues that Orestes has transgressed both sacred and profane law by murdering his own mother. Even though she committed adultery, and killed his father, she should have been tried in a court of law. For her murder and that of Pyrrhus, Molossus demands a lingering death with brutal torture. Orestes' defence is that the restoration of his sanity proves that divine justice approves his actions. Dracontius allows some space for the gods in this argument as well as in having Minerva casting a decisive vote that Orestes be acquitted. Orestes leaves the court in triumph with this two sisters and Pylades. The poem ends with an invocation to the gods to spare the Greeks from further atrocities and crimes.

Edith Hall (2005:68) maintains that along with the interpretations of Ovid and Seneca, Dracontius' version of the myth was influential in shaping medieval

22 Dracontius' adaptation of the dream device familiar in epic poetry, especially the vision of Hector appearing to Aeneas on the night of the fall of Troy, appears to be unique in the respect that two characters experience the same dream simultaneously.

23. Dracontius is unique in giving Molossus this role. 
mythological compendia which provided material for English, French, German and Italian drama and opera before the nineteenth century. The more feminine, sexualised side of the Clytaemestra of the Roman poets is certainly prominent in the Orestis tragoedia, but she is still a virago (752) who boldly tackles all obstacles to realising her ideal of a union with her unsophisticated but sexy lover.

The conduct of the couple, their adultery and the further crimes that serve it and are caused by it, are condemned throughout the poem. ${ }^{24}$ This unambiguous censure of adultery prompts the question of whether one should read the Orestis tragoedia as an allegory of the Biblical commandment "Thou shalt not commit adultery". It seems unnecessary to confine the purpose of the poem in this way, ${ }^{25}$ although Dracontius may have been influenced by his knowledge of Christian ethics and morality in his adaptation of the myth. There has been extensive debate ${ }^{26}$ about whether this is a Christian version of the myth, but the current consensus is that it is not the case. Dracontius is not the only poet in late antiquity whose Christian faith coexists easily with his secular interest in pagan literature. $\mathrm{He}$ has retold the famous plot of numerous ancient tragedies as the story of an adulterous couple whose passionate obsession with their relationship leads them to a heinous misdeed and a total disregard for the morality of civilised society. Dracontius' version shows that their crime is punished in a fitting way. Orestes is a hero who has the same qualities as his father, the good Agamemnon created by Dracontius. Thus the poem may be read as a tale of the punishment of vice and the reward of virtue. The striking feature of the poem is undoubtedly the originality of the depiction of Clytaemestra and Egistus.

\section{BIBLIOGRAPHY}

Bright, D F 1987. The miniature epic in vandal Africa. Norman \& London: University of Oklahoma Press.

Bouquet, J \& Wolff, E (eds.) 2002. Dracontius Oeuvres III. Paris: Les Belles Lettres.

Croisille, J M 1964. Le personnage de Clytemnestre dans l'Agamemnon de Sénèque. Latomus 23:464-472.

Crump, M M 1978. The epyllion from Theocritus to Ovid. New York: Gatland.

24 One may compare the last line of De Raptu Helenae: crimen adulterii talis vindicta sequatur (may such vengeance follow the crime of adultery).

25 Bright 1987:205 goes as far as making a case that Dracontius in the Orestis tragoedia "is influenced strongly by the intention to measure conduct against the standard of the Law of God, i.e., the Ten Commandments".

26 See for instance Schetter 1994:367-369, Simons 2005:371. 
Edwards, M J 2004. Dracontius the African and the fate of Rome. Latomus 63:151-160.

Fontaine, J 1981. Naissance de la poésie dans l'Occident chrétien. Paris: Etudes Augustiniennes.

George, J W 2004. Vandal poets in their context. In Merrills, A H (ed.), Vandals, Romans and Berbers: New perspectives on late antique North Africa, 133-143. Aldershot: Ashgate.

Hall, E 2005. Aeschylus' Clytemnestra versus her Senecan tradition. In Macintosh, F, Michelakis, P, Hall E, \& Taplin, O (eds.), Agamemnon in performance, 53-75. Oxford: Oxford University Press.

Kaufmann, H 2006. Missing hierarchy: The gods in Dracontius' Medea (Romul. 10). Archivum Bobiense 27-28:79-101.

Langlois, P 1959. Dracontius. In Reallexikon für Antike und Christentum 4, 250-69. Stuttgart: Anton Hiersemann.

Mader, G 1988. Fluctibus variis agor: An aspect of Seneca's Clytemnestra portrait. Acta Classica 31:51-70.

Moussy, C \& Camus, C 1985. Dracontius Oeuvres I. Paris: Les Belles Lettres.

Schetter, W 1994. Über Erfindung und Komposition des 'Orestes' des Dracontius zur Spätantiken Neugestaltung eines klassischen Mythos. In Zwierlein, O (ed.), Willy Schetter: Kaiserzeit und Spätantike 342-369. Stuttgart: Franz Steiner.

Simons, R 2005. Dracontius und der Mythos: Christliche Weltsicht und pagane Kultur in der ausgehenden Spätantike. Munich: K G Saur.

Wolff, E (ed.) 2002. Dracontius Oeuvres IV. Paris: Les Belles Lettres. 